\title{
Effect of turning out dairy cows to pasture on milk somatic cell count
}

\author{
Dominique POMIÈs ${ }^{\mathrm{a} *}$, Patrick GASQUI ${ }^{\mathrm{b}}$, Jacques BONY ${ }^{\mathrm{c}}$, \\ Jean-Baptiste COULON ${ }^{\mathrm{b}}$, Jacques BARNOUIN ${ }^{\mathrm{b}}$
}

a Unité de Recherches sur les Herbivores, INRA, Theix, 63122 Saint-Genès Champanelle, France,
b Unité de Recherche Épidémiologie Animale, INRA, Theix,
63122 Saint-Genès Champanelle, France,
c Domaine Expérimental du Roc, INRA, 63210 Orcival, France

(Received 4 May 1999; accepted 14 October 1999)

\begin{abstract}
An increase in milk somatic cell count is often observed in commercial herds when cows are on pasture during summer. The objective of this study was to check, in experimental conditions, if this effect is due to the turning out to pasture. Three groups of cows were observed for five weeks: 10 cows with low somatic cell count $(<100000$ cells $/ \mathrm{ml})$ stayed in the cow-shed during the entire study; 10 cows with low somatic cell count and 10 cows with high somatic cell count (> 300000 cells $/ \mathrm{ml}$ ) went to pasture after two weeks in the cow-shed. The measurements were: milk production, chemical composition, somatic cell count, pathogens in the milk and plasma markers. Milk production and fat content were higher in cows turned out to pasture than in cows staying in the cow-shed $(+1.4 \mathrm{~kg}$ and $+3.4 \mathrm{~g} / \mathrm{kg})$. No effect of turning out to pasture on milk protein content, milk somatic cell count and plasma markers level was noticed. In conclusion, the increase in milk somatic cell count observed in summer seems not to be due to the environmental change when cows turned out to pasture. Alternative explanations are suggested.
\end{abstract}

dairy cow / milk / somatic cell count / pasture

Résumé — Effet de la mise à l'herbe des vaches laitières sur la numération cellulaire du lait. Dès la période de mise à l'herbe, et jusqu'à la fin de l'été, on observe dans de nombreux élevages laitiers une augmentation de la numération cellulaire par rapport à la période hivernale de l'ordre de 100000 cellules par ml, d'autant plus importante que la numération cellulaire initiale est élevée. Il n'est cependant pas aisé de savoir à quels facteurs attribuer cette augmentation : changement d'environnement ; infections mammaires plus nombreuses ; stade de lactation ; modification des pratiques de traite ; etc. L'objectif de cet essai était de vérifier, dans des conditions expérimentales, si la mise à l'herbe des troupeaux laitiers entraîne des variations significatives de la numération cellulaire de leur

\footnotetext{
* Correspondence and reprints

Tél.: +33 (0)4 736245 94; fax: +33 (0)4 736241 18; e-mail: pomies@ clermont.inra.fr
} 
lait. Trois lots de 10 vaches laitières de race Holstein ont été constitués : un lot témoin $(\mathrm{C})$ à numération cellulaire basse $(<100000 / \mathrm{ml})$ a été laissé en stabulation et nourri au foin durant les 5 semaines de l'étude ; un lot (PL) à numération cellulaire basse et un lot (PH) à numération cellulaire élevé (> 300000 / ml) ont été mis à l'herbe à partir de la 3 3 semaine. La production laitière, la numération cellulaire du lait, sa composition chimique, le statut infectieux des mamelles ainsi que des paramètres plasmatiques caractéristiques de l'inflammation ont été mesurés individuellement. La production laitière et le taux butyreux des lots PL et PH après la mise à l'herbe ont été supérieurs à ceux du lot $\mathrm{C}(+1,4 \mathrm{~kg}$ et $+3,4 \mathrm{~g} / \mathrm{kg})$, alors que le taux protéique est resté identique. La mise à l'herbe n'a pas entraîné d'augmentation du nombre de vaches infectées par des germes pathogènes majeurs au niveau de la mamelle. Quel que soit le lot, aucun marqueur sanguin de l'inflammation n'a présenté de différence au cours de l'essai. De même, la numération cellulaire du lait n'a pas différé significativement entre le début et la fin de l'essai, pour un même lot. Il a cependant été observé une variabilité individuelle importante de l'évolution de la numération cellulaire lors de la mise à l'herbe, particulièrement marquée dans le lot $\mathrm{PH}$, que l'on ne retrouve pas dans le lot témoin. Nous n'avons donc pas pu mettre en évidence d'effet direct de la mise à l'herbe sur la numération cellulaire du lait, quelle que soit la valeur initiale de celle-ci. Les augmentations de la numération cellulaire au cours de la période estivale, qui semblent débuter avec la mise à l'herbe, ne sont donc pas dues à l'effet propre du changement d'environnement physique, mais plutôt à d'autres facteurs (physiologiques, sanitaires, climatiques ...) que la période de pâturage contribue à exacerber.

vache laitière / lait / numération cellulaire / mise à l'herbe

\section{INTRODUCTION}

A better knowledge of the variation factors of cow's milk somatic cell count appears to be crucial because cell count is a predominant criterion for milk quality and for the price paid to farmers. Milk somatic cell count is below 100000 cells per millilitre in healthy udders [3, 14]. It increases sharply in case of udder infection, due to the onset of local inflammation [17]. In cows free of clinical mastitis, somatic cell count also increases with ageing and in late lactation, but in a more restricted manner [2, 7]. Also, some husbandry conditions (stress, repeated walk) may induce a significant increase in somatic cell count [10], as can do the nature of feeding [5].

Whereas somatic cell count is generally stable during winter, it increases in many herds from turning out to pasture till the end of summer. According to a study conducted in France on 960 farms [12], this increase, of about 100000 cells per $\mathrm{ml}$, is likely to be the more important when the initial level is higher. However, the factors responsible for that summer increase are not easily identi- fiable: more frequent udder infections, lactation stage, changes in milking practices [1], climatic stress [18] and pasture-related factors, all can be involved. A trial was therefore carried out in an experimental farm to explore the specific effect of the turning out to pasture period upon dairy cow's milk somatic cell count, according to its baseline level and taking the udder infection status into account.

\section{MATERIALS AND METHODS}

\subsection{Animals and feeding}

The trial was carried out over 5 weeks, $\mathrm{Wk}_{1}$ to $\mathrm{Wk}_{5}$ (28 April-1 June 1997), in 30 Holstein dairy cows (11 primiparous and 19 multiparous) in full lactation (190 days on average at the beginning of the trial) selected from the experimental herd of Inra's Orcival farm (Domaine du Roc). Three 10-cow groups were formed $(\mathrm{C}=\mathrm{Control}$ group kept in cow-shed, with low somatic cell count; PL: group turned out to Pasture, with Low somatic cell count; PH: group 
turned out to Pasture with High somatic cell count) based on lactation number and milk yield, as recorded over the 8 weeks preceding the beginning of the trial. Animals from $\mathrm{C}$ and PL groups had somatic cell counts below 100000 cells $/ \mathrm{ml}$ at the beginning of the trial (geometrical mean) and no major pathogens in milk. Animals of PH group had a mean somatic cell count over 300000 cells $/ \mathrm{ml}$ at the beginning of the trial, and nine of them presented one or several quarters with major pathogen infection (Streptococcus uberis, Staphylococcus aureus or Escherichia coli). One cow from the PL group was excluded from the study because of clinical mastitis detected before the turning out to pasture. Also, following the occurrence of clinical mastitis in two multiparous cows during the last week (one in $\mathrm{C}$ group and one in PL group), the variables corresponding to these animals were not taken into account in statistical analysis for the relevant period.

During the two weeks preceding turning out to pasture ( $\mathrm{Wk}_{1}$ and $\left.\mathrm{Wk}_{2}\right)$, all cows were housed in cow-shed and fed a hay-based diet (12 kg/day) supplemented by barley $(8.1 \mathrm{~kg} /$ day on average), soybean meal $(0.7 \mathrm{~kg} /$ day on average $)$ and mineral supplement ( $250 \mathrm{~g} /$ day) to cover requirements.

In the course of the 3 following weeks $\left(\mathrm{Wk}_{3}, \mathrm{Wk}_{4}\right.$ and $\left.\mathrm{Wk}_{5}\right)$, animals of the $\mathrm{C}$ group were kept in cow-shed with the same diet, whereas cows from the PL and $\mathrm{PH}$ groups were turned out to pasture with a 4-day dietary transition and were then led to a Ray Grass plot, 700 metres away from the milking parlour (controlled rotating grazing). The cows from PL and PH groups returned to the cow-shed twice a day and ate on average $0.3 \mathrm{~kg}$ barley and $250 \mathrm{~g}$ mineral supplement, after the morning milking.

\subsection{Measurements}

Milk yield was weighed for each cow after each milking. Chemical composition (milk fat and protein contents) was anal- ysed on two days each week (morning and evening milking). Milk somatic cell count was measured five days a week (morning and evening milking on two days; only morning milking on three days). On three days during $\mathrm{Wk}_{2}, \mathrm{Wk}_{4}$ and $\mathrm{Wk}_{5}$ weeks, quarter milk aseptic samples were collected from all the cows according to Mialot's method [16]. After bacterial isolation, these samples were used to characterise the pathogenic germs present in the udders [17]. A cow was considered infected when at least 10 colonies of the same major pathogen were isolated from at least one quarter. To measure the plasma parameters which characterise infection, blood samples were collected on heparin from the caudal vein on the same dates. Total protein content (PT) (Ecoline Merck Kit, code 14854), albumin (AL) (Ecoline Merck Kit, code 14819), IgG1 immunoglobulins (IG) (opacimetric method using a specific antiserum provided by Levieux, INRA Theix, France) and ceruloplasmin (CE) were assayed in each plasma sample obtained by immediate centrifugation [6]. Based on these data, total globulin content $(\mathrm{GL}=\mathrm{PT}-\mathrm{AL})$ and the $\mathrm{AL} / \mathrm{GL}$ ratio (= RA) were computed, the latter being lower in the cows where inflammation developed [4].

\subsection{Data analysis}

Mean milk yield and composition (milk fat, protein and decimal logarithm of somatic cell count) were computed weekly for each cow in $\mathrm{Wk}_{2}, \mathrm{Wk}_{4}$ and $\mathrm{Wk}_{5}$ weeks. Daily individual values of plasma components (CE, GL, IG and RA) were analysed during the same periods. For each of the three periods and for each of the height variables to be accounted for, the weekly means or daily individual values were processed by analysis of variance (GLM procedure, SAS 1987). For weeks $\mathrm{Wk}_{4}$ and $\mathrm{Wk}_{5}$ the full initial model, considering the initial value (in $\mathrm{Wk}_{2}$ ) as a covariant, revealed no lactation number effect (primiparous vs. multiparous) 
nor any group factor interaction. The results obtained were similar and these two periods were combined; a new $\mathrm{Wk}_{4-5}$ period was constructed by averaging the variable values measured during $\mathrm{Wk}_{4}$ and $\mathrm{Wk}_{5}$. From this new full model a more synthetic final model was obtained, whose results, processed by analysis of variance, are shown in Table I. As a supplement to the table, Figure 1 represents the daily means of somatic cell counts observed in each group after decimal logarithmic transform.

\section{RESULTS AND DISCUSSION}

The milk yield and fat content of the two groups turned out to pasture (Tab. I) were significantly higher than those of the group kept in the cow-shed $(+1.4 \mathrm{~kg}$ and $+3.4 \mathrm{~g} / \mathrm{kg}$, respectively during the $2 \mathrm{nd}$ and 3rd weeks following turning out to pasture). These changes are classically observed when turning out to pasture follows a winter diet based on hay or grass silage [9]. By contrast, the protein content was identical in all three groups, contrary to previous observations $[8,9]$.

Whereas in $\mathrm{Wk}_{2}$ none of the $\mathrm{C}$ or $\mathrm{PL}$ cows had major pathogen infection of the udder, five $\mathrm{C}$ and three PL cows were infected in $\mathrm{Wk}_{4}$, and only three and zero in $\mathrm{Wk}_{5}$. In the PH group, the 9 cows that were infected in $\mathrm{Wk}_{2}$ were still infected in $\mathrm{Wk}_{4}$ and $\mathrm{Wk}_{5}$. Twenty-four of the twenty-six

Table I. Milk yield, fat and protein contents, somatic cell count and plasma parameters of three groups of cows (C: control group kept in cow-shed; PL: group turned out to pasture, with low somatic cell count; PH: group turned out to pasture with high somatic cell count), before $\left(\mathrm{Wk}_{2}\right)$ and after $\left(\mathrm{Wk}_{4-5}\right)$ turning out to pasture.

\begin{tabular}{lccccc}
\hline & & \multicolumn{3}{c}{ Group } & RSD* \\
\cline { 3 - 5 } & & $\mathrm{C}$ & $\mathrm{PL}$ & $\mathrm{PH}$ & \\
\hline Milk yield (kg/day) & $\mathrm{Wk}_{2}$ & 20.3 & 19.5 & 20.7 & 3.0 \\
& $\mathrm{Wk}_{4-5}$ & $19.8^{\mathrm{a}}$ & $21.0^{\mathrm{ab}}$ & $21.4^{\mathrm{b}}$ & 1.4 \\
Milk fat content (g/kg) & $\mathrm{Wk}_{2}$ & 36.2 & 36.0 & 36.4 & 4.0 \\
& $\mathrm{Wk}_{4-5}$ & $36.5^{\mathrm{a}}$ & $40.3^{\mathrm{b}}$ & $39.4^{\mathrm{b}}$ & 2.5 \\
Milk protein content (g/kg) & $\mathrm{Wk}_{2}$ & 31.2 & 32.4 & 32.3 & 1.7 \\
& $\mathrm{Wk}_{4-5}$ & 32.1 & 32.3 & 32.7 & 0.8 \\
Milk somatic cell count (log ${ }_{10}$ ) & $\mathrm{Wk}_{2}$ & $4.84^{\mathrm{a}}$ & $4.81^{\mathrm{a}}$ & $5.46^{\mathrm{b}}$ & 0.21 \\
& $\mathrm{Wk}_{4-5}$ & 5.12 & 5.19 & 5.19 & 0.17 \\
Total protein content - albumin (g/l) & $\mathrm{Wk}_{2}$ & 52.5 & 47.3 & 51.3 & 4.9 \\
& $\mathrm{Wk}_{4-5}$ & 51.8 & 51.1 & 51.5 & 4.9 \\
Albumin / (protein content - albumin) & $\mathrm{Wk}_{2}$ & 0.68 & 0.75 & 0.70 & 0.08 \\
& $\mathrm{Wk}_{4-5}$ & 0.69 & 0.70 & 0.68 & 0.07 \\
Immunoglobulins (g/l) & $\mathrm{Wk}_{2}$ & 24.7 & 24.3 & 26.1 & 3.3 \\
& $\mathrm{Wk}_{4-5}$ & 28.0 & 28.4 & 27.4 & 2.4 \\
Ceruloplasmin (oxydasic unit/l) & $\mathrm{Wk}_{2}$ & 41.4 & 36.8 & 37.8 & 6.0 \\
& $\mathrm{Wk}_{4-5}$ & 37.2 & 38.4 & 37.4 & 4.6 \\
\hline
\end{tabular}

*: Residual standard deviation.

ab: Values with different letters in a row are significantly different $(P<0.05)$. 


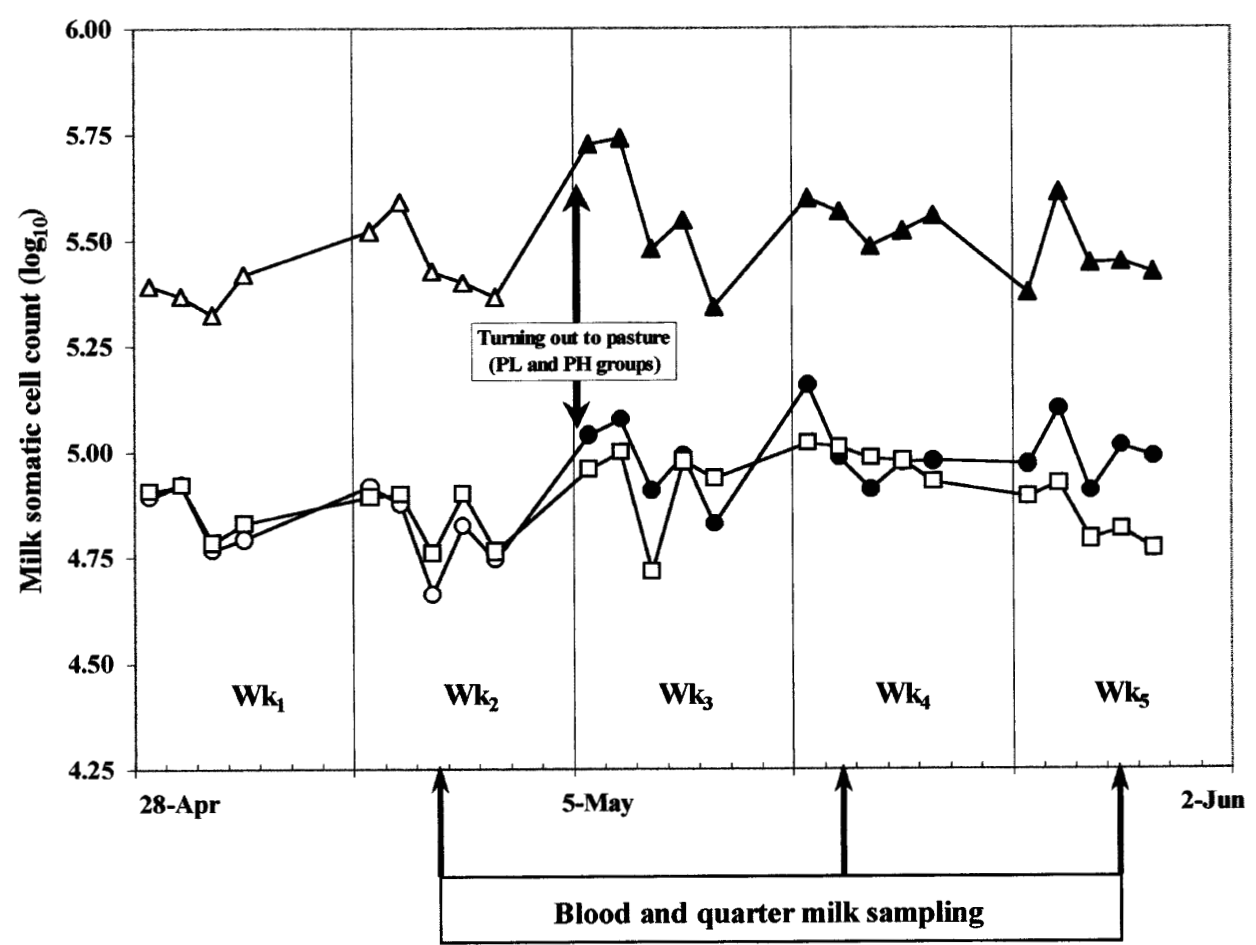

Figure 1. Milk somatic cell count: control group kept in cow-shed $=\square(\mathrm{C})$; group turned out to pasture, with low somatic cell count $=\mathrm{O}-\mathrm{PL}$ ); group turned out to pasture with high somatic cell count $=\triangle-\mathbf{\Delta}(\mathrm{PH})$.

infected quarters were infected by Staphylococcus aureus. Turning out to pasture therefore did not induce any durable increase in the number of cows infected by major pathogens.

There was no significant difference in circulating protein markers of inflammation (GL, RA, IG, CE) between $\mathrm{Wk}_{2}$ and $\mathrm{Wk}_{4-5}$ periods.

Milk somatic cell count, reflecting udder inflammation, was higher in the $\mathrm{PH}$ group than in the other two, as expected by the protocol. Regardless of the group, turning out to pasture did not increase significantly somatic cell count. However, individual changes in somatic cell count after turning out to pasture were highly variable between cows, especially in the $\mathrm{PH}$ group. Between weeks $\mathrm{Wk}_{2}$ and $\mathrm{Wk}_{3}$, the difference in somatic cell count varied between -94000 and $+1048000 / \mathrm{ml}$ in the PH group and between -173000 and $+249000 / \mathrm{ml}$ in the PL group. This variation was much more restricted in the control group ( -20000 to +59000/ ml).

In this study, turning out to pasture was relatively quick: only four days of transition. However there was little physical stress: the distance the cows had to walk to go from the milking parlour to pasture was about $2.8 \mathrm{~km}$ per day and the mean plot area was 5 hectares. This husbandry method induced no marked changes in somatic cell count, contrary to what classically happens 
when turning to out pasture is abrupt and physical exercise is greater $[11,15]$. Our results therefore clearly confirmed the observations made in experimental farming under close conditions of turning out to pasture, in a large population of cows [7].

Somatic cell count increases, often described during the summer period $[1,13]$ and apparently beginning with pasture, are not directly linked to environmental changes, but rather to other physiological, sanitary or climatic factors that are enhanced during the pasture grazing period $[13,15]$.

\section{REFERENCES}

[1] Agabriel C., Coulon J.B., Sibra C., Journal C., Hauwuy A., Facteurs de variation de la numération cellulaire du lait en exploitation, Ann. Zootech. 46 (1997) 13-19.

[2] Auldist M.J., Coats S., Rogers G.L., McDowell G.H., Changes in the composition of milk from healthy and mastitic dairy cows during the lactation cycle, Austr. J. Exp. Agric. 35 (1995) 427-436.

[3] Badinant F., Maîtrise du taux cellulaire du lait, Rec. Méd. Vét. 170 (1994) 419-427.

[4] Barnouin J., Chacornac J.P., Ansaoui C., El Idilbi N., Comment dépister les déséquilibres biologiques et les troubles de santé chez la vache laitière dans le cadre d'études écopathologiques ?, Vet. Res. 25 (1994) 104-109.

[5] Barnouin J., Chassagne M., Aimo I., Dietary factors associated with milk somatic cell counts in dairy cows in Brittany, Prev. Vet. Med. 21 (1994) 299-311.

[6] Chacornac J.P., Barnouin J., Raboisson T., Micro-dosage automatisé de la céruloplasmine plasmatique par mesure de l'activité oxydasique chez les bovins et les ovins, Reprod. Nutr. Dév. 26 (1986) 417-427.

[7] Coulon J.B., Dauver F., Garel J.P., Facteurs de variation de la numération cellulaire du lait chez des vaches laitières indemnes de mammites cliniques, INRA Prod. Anim. 9 (1996) 133-139.

[8] Coulon J.B., D'Hour P., Petit M., Influence of transition feeding pattern on milk production at the turnout of cows to pasture, Livest. Prod. Sci. 20 (1988) 119-134.

[9] Coulon J.B., Garel J.P., Hoden A., Évolution de la production et de la composition du lait à la mise à l'herbe, Bull. Tech. C. R. Z. V. Theix INRA 66 (1986) 23-29.

[10] Coulon J.B., Pradel P., Effect of walking on roughage intake and milk yield and composition of Montbéliardes and Tarentaises dairy cows, Ann. Zootech. 46 (1997) 139-146.

[11] Coulon J.B., Pradel P., Cochard T., Poutrel B., Effect of extreme walking conditions for dairy cows on milk yield, chemical composition, and somatic cell count, J. Dairy Sci. 81 (1998) 994-1003.

[12] Deraedt M., Évolution des numérations cellulaires des laits de mélange et relation avec les performances technico-économiques des troupeaux, Synthèse Nationale Écolait 1995, Bureau Technique de Production Laitière, 1996.

[13] Harmon R.J., Physiology of mastitis and factors affecting somatic cell counts, J. Dairy Sci. 77 (1994) 2103-2112.

[14] Jacquet J., Les cellules somatiques du lait, in : le lait, matière première de l'industrie laitière, Ed. INRA-CEPIL, Paris, 1987, pp. 207-212.

[15] Lamarche A., Martin B., Hauwuy A., Coulon J.B., Poutrel B., Evolution of cow's milk somatic cell count according to udder infections condition during highland pasture grazing, Ann. Zootech. 49 (2000) 43-53.

[16] Mialot J.P., Technique de prélèvement de lait pour examen bactériologique, Rec. Méd. Vét. 159 (1983) 1057-1058

[17] Poutrel B. Généralités sur les mammites de la vache laitière, Processus infectieux, épidémiologie, diagnostic, méthodes de contrôle, Rec. Méd. Vét. 161 (1985) 497-511.

[18] Shearer J.K., Bray D.R., Maintaining udder health and milk quality during periods of hot weather, Dairy Food Environ. Sanit. 15 (1995) 368-370. 